UDC 373.5.015.31:784.1.071.2

DOI: $10.52534 / \mathrm{msu}-\mathrm{pp} .7(3) .2021 .87-93$

Liudmyla I. Moroz ${ }^{*}$ Aleksandr D. Safin, Olena O. Andrusik

Pavlo Tychyna Uman State Pedagogical University

20300, 2 Sadova Str., Uman, Ukraine

\title{
Influence of Emotions on the Effectiveness of the Creative Process
}

\author{
Article's History: \\ Received: 03.06.2021 \\ Revised: 27.07.2021 \\ Accepted: 15.08.2021
}

\section{Suggested Citation:}

Moroz, L.I., Safin, A.D., \& Andrusik, O.O. (2021). Influence of emotions on the effectiveness of the creative process. Scientific Bulletin of Mukachevo State University. Series "Pedagogy and Psychology", 7(3), 87-93.

\begin{abstract}
The relevance of this study is determined by the importance of issues of interrelation of the emotional component of activity with the final results obtained in the course of creative research in different areas, as well as the practical significance of studying the problems of the influence of a wide range of emotional experiences on the overall effectiveness of the creative process. The purpose of this study is to determine the extent to which the emotional component of creativity influences the effectiveness of the creative process, regardless of the field of activity. The leading approach in this study was a combination of theoretical study of various aspects of creative activity in general, with a structural analysis of the features of the influence of the emotional component on the overall effectiveness of the creative process in various areas of activity. The results obtained in the course of this study demonstrate the wide range of possibilities for the rational use of personal emotional displays on the specific issues of applying creative activity in general and in terms of assessing the effectiveness of the creative process in particular. The results and conclusions of this paper have significant practical value for representatives of creative professions, researchers of psycho-emotional manifestations of personality in the conduct of creative activity, and will be useful for the next generations of researchers of various aspects of the influence of emotional experiences on the effectiveness of the creative process. The results will be useful as a scientific basis for the author to conduct further full-fledged research into the wide range of issues presented in this paper, thereby contributing to further objective and qualitative coverage of the subject matter
\end{abstract}

Keywords: creative process, emotional sphere, creative abilities, effectiveness of creative activity, emotions in creativity

\section{INTRODUCTION}

The influence of the emotional component on the overall performance of creative activity is significant regardless of the scope of the individual's creativity. Emotions can both provide an additional impetus to creative inspiration and take away the strength and energy needed to realise the various tasks of the creative process. Maintaining control over emotional displays should be considered an important condition for the effectiveness of any creative activity, as excessive emotionality can have a negative impact on the realisation of creative intentions and prevent the creative individual from effectively addressing the challenges he or she faces.

There is no consensus among modern researchers on the quality of the impact of the emotional component of human activity on the overall effectiveness of the creative process. The realisation of creative ideas, itself associated with a high emotional high, which is usually followed by an emotional low, together represents the emotional palette characteristic of the creative profession [1]. Furthermore, it is not always possible to measure the real impact of emotions on the effectiveness of the creative process, as emotional experiences cannot be accurately measured. In the same way, it is impossible to fully understand and measure the depth and level of increase in creative activity under the influence of emotions of one kind or another.

At the same time, the influence of various emotional experiences is reflected in the work of composers and poets, writers and artists, and representatives of almost all creative professions, who are in one way or another associated with the need for artistic expression of emotion in works of various kinds of art. The methods used for artistic expression vary depending on the art form and the manner of each 
particular author, but what remains constant are the key principles of artistic reflection of emotional experience, based on maintaining the sincerity of the feelings, sensations and emotions conveyed [2].

The analysis of artworks of various genres and types of modern art and art of past centuries allows us to conclude that the revealed dominant personal subtexts and the meaning of the emotional component which dominates in a particular work of fiction allow us to reconstruct to a certain extent both separate fragments of the conceptual scheme of the author of the artwork and the entire work in its completed form. Thus, it becomes possible not only to describe the ideological orientation and motifs of each artistic work, but also to identify the specific personality traits of its author, with his characteristic emotional background and the role of the emotional components of his personality in the effectiveness of the creative process.

The imagery in any work of fiction is a reflection of the author's ideas, influenced by various emotions that are characteristic of certain periods of the creative process. The artistic thinking of each participant, at its core, contains a high level of perception of artistic values, reflected in the artwork they create, is in one way or another a reflection of surrounding reality [3]. In this context, his emotional experience plays an essential role, as it affects both the quality of the images depicted in the work and the perception of them by generations of future admirers of the author's work.

The emotional palette of any artistic work is a qualitative reflection of the author's perception of reality through the means of self-expression available to the artist. It could be the notes of a piece of music or the colours of a painting. The various ways of conveying emotional moods in music, painting or dance cultures of different nations help to enrich the national cultural heritage of any nation and create conditions for the full creative development of cultural and artistic figures, regardless of their affiliation to a particular occupation [4]. The influence of emotions on the effectiveness of creative activity plays a defining role in this context [5].

\section{MATERIALS AND METHODS}

The methodology of this study is based on a combination of theoretical research into various aspects of creative activity in general, with a structural analysis of the features of the influence of the emotional component on the overall effectiveness of the creative process in various fields of activity. Theoretical investigation of different aspects of creativity from the standpoint of assessing the influence of author's emotions on the quality of creative process development contributes to a better understanding of its essence, which, combined with the analysis of the influence of emotions on the quality of creative activity in specific types contributes to a holistic picture of scientific research, based on the statement of the problems of creativity and research into the relationship between the emotional component and the quality of creative expression in general. The stated research methods in the above combination contribute to the qualitative disclosure of the essence of the issues of the influence of the emotional component on the effectiveness of conducting creative activity.

The basis for this study was the numerous theoretical and practical developments of Ukrainian and foreign researchers on the relationship and mutual influence of the emotional component of creativity and effectiveness of creative endeavours, regardless of the particular branch of creative activity. The theoretical basis of this paper has been selected in strict accordance with the subject matter to be considered and contributes to the highest possible quality of disclosure within the broad range of stated issues. In order to form the most qualitative and objective picture of scientific research and to facilitate the perception of the information presented, all materials borrowed from foreign sources and presented in this study were translated into English [5].

This study was performed in several stages:

1. The first stage of this study involved a theoretical analysis of Ukrainian and foreign publications on the influence of emotions on the effectiveness of creative activity, in relation to different types of contemporary art and art of past years, in order to identify the situation, to date the system of theoretical views of the researchers on the issues brought for consideration in this research paper.

2. The second stage of the study included a structural analysis of the influence of the emotional factor on the effectiveness of the creative process, both in general and in the context of various types of creative activity in particular. At the same time, a comparative analysis was made of the results obtained with similar results by other authors.

3. At the end of this study, the final conclusions of the research study were provided, based on the theoretical and practical results obtained. Overall, the findings and conclusions of this research act as a qualitative reflection of some of the range of work aimed at identifying the impact of emotions on the effectiveness of creative activity in its various sectors.

\section{RESULTS AND DISCUSSION}

The influence of emotions on the effectiveness of the creative process in various fields of activity manifests itself in various forms and variations, and in general the focus of such influence is determined both by the psychotype of the individual and by the scope of application of the creative abilities inherent in it by nature. The conditions that influence the individual's emotional attitude towards the situation in the creative activity process are also important, taking into account their individual characteristics and abilities for creative fulfilment in specific activities.

There are good reasons to argue that emotion can lead to significant creative breakthroughs and achievements in different, absolutely mutually related creative activities. The diagram in Figure 1 reflects the main aspects of emotions in creativity in terms of enhancing the effectiveness of the creative process and opening up additional possibilities in creative activity. 


\section{EMOTIONS IN CREATIVITY}

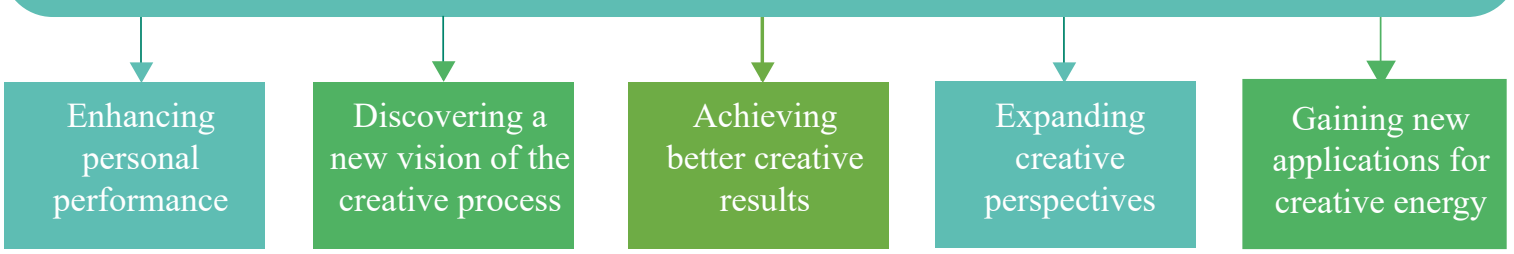

Figure 1. Main aspects of the use of emotions in creativity, in terms of enhancing the effectiveness of the creative process and opening up additional possibilities in creative activity

The positive impact of emotional elation on the end results of creative activity can be manifested both in the individual receiving additional energy for creative endeavours and in the individual's empowerment in a particular activity, as well as in the discovery of abilities previously unknown to him or her. There have been many cases of so-called "creative ecstasy" in which members of various creative professions, influenced by an increase in the general emotional background, have virtually lost their sense of time and reality and created masterpieces of painting, music, literature and other applications of creative energy.

At the same time, negative emotions can be destructive and negatively reproduced in various manifestations of the creative activity of the individual, causing a loss of faith in themselves and their abilities, a decline of spirit and further creative and social degradation [5]. Creative people are prone to emotional swings, ranging from the height of creativity to a complete inability to make any decisions or carry out any activity at all. Moreover, negative emotions can affect health in general and the nervous system in particular, leading to illness and an inability to be creative.

The influence of emotions on the effectiveness of the creative process can be determined both by the quality of the emotional experiences and by their frequency. In addition, as mentioned above, personality psychotype and occupation also play a significant role in assessing the level of influence of emotions of different qualities on the creative process. Figure 2 presents a diagram of the relationship between the quality of a person's emotional expressions and various aspects of creative activity. The proposed scheme can be successfully applied to all creative activities without exception.

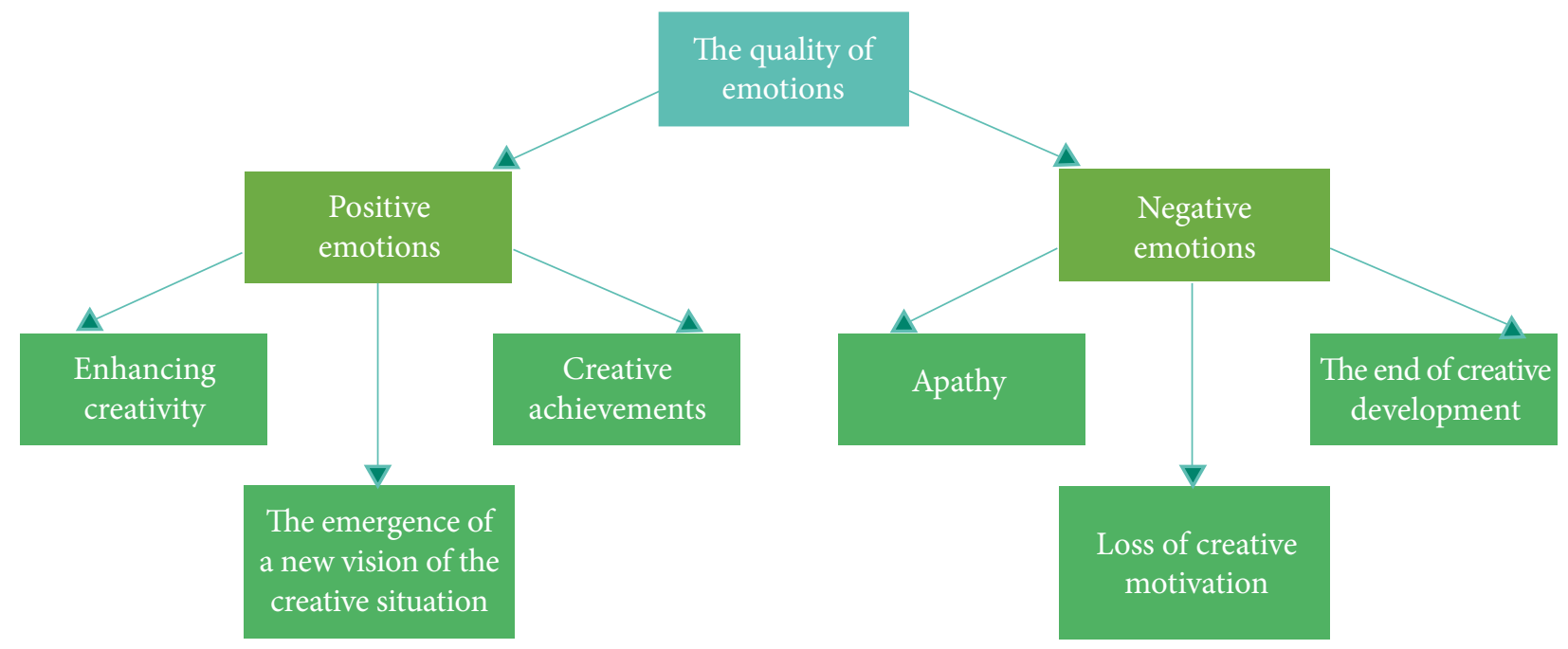

Figure 2. The relationship between the quality of personal emotional expression and various aspects of creative activity

At the same time, we all know of numerous counterexamples that prove the positive influence of tragic emotions in a person's life on their creativity, which has led to the creation of outstanding works of art. A striking example is the poetry of A. Akhmatova and S. Yesenin, as many of their famous poems ("In Memory of Mikhail Bulgakov", "Gray-eyed King" "Maple You are my fallen ..." and others) were written during difficult periods of life, which did not contribute to positive emotions.
The emotional colouring of a work of fiction affects the quality of perception, with the level of readiness of the reader or viewer playing a minor role in this context. The emotions that the author puts into his own work create a certain background through which the viewer, reader or listener perceives the features of the storyline and the artistic techniques used in the work, which contribute to creating a coherent picture of the artwork. The main criteria for assessing the impact of the emotional background of a work 
of fiction on perception should be highlighted:

- the mood when getting acquainted with a work of fiction;

- emotions that the work evokes in the subject who gets acquainted with it;

- the emergence of a desire to discuss the features of the work of fiction or the complete absence of such;

- the level of stability of the emotional state, which arises after acquaintance with the work, after some time;

- empathy for the characters in a work of fiction or the characters represented in it.

At the same time, the influence of emotions on the effectiveness of the creative work can be seen in the creation of a set of dominant emotions in a work of fiction, an example of which are the ambivalent emotions of disgust, suffering, despair, longing, fear, horror and happiness, joy and pleasure in the novel The Gift by V.V. Nabokov. In particular, the ambivalent emotions of "happiness - unhappiness" are used by the author to artistically portray the emotional component of the concept of "creativity as a game". The dominant emotion of this concept is represented by the emotion of happiness, which conceptually includes "crime", "fear", "madness" and "illness" [6]. In this example, we can trace the diversity of the emotional palette of the concept of a work of fiction, which includes the complex expression of a whole range of different, often contradictory emotions. The diversity of the emotional palette of a work of fiction makes it particularly perceptive in terms of the possibilities of conveying the theme and idea of a work of fiction through a set of artistic images.

The emotions that are conveyed in a work of fiction through the means of artistic representation form the characteristic handwriting of a particular author of a work of fiction. They can be expressed in certain word forms or the colour palette of a painting - the essence does not change. It should be noted the uniqueness of the author's reflection of certain emotions or their combination, in specific techniques inherent in a particular author of the work of fiction. This is the uniqueness of the artist's creative handwriting, his identity and ability to express themselves through only his own artistic techniques [7].

Thus, the influence of emotions on the effectiveness of the creative process is a complex concept, further study of which will enrich the current understanding of the various aspects of creativity in general. The emotional sphere is of great importance in all spheres of creative activity without exception. Under the influence of emotions and orientation, creative individuals create works that occupy a worthy place in the treasury of World Art Culture. The influence of the emotional component on the creative process is inextricably linked to the inner world of the individual, his desire to create artistic works, through the display of his own vision of the world using the principles of expressiveness of artistic images [9].

The influence of emotions on the effectiveness of the creative process is not fully understood, as it is impossible to fully ascertain the level of emotional expression of an individual and to trace all of his or her emotional attitudes and experiences. In addition, much depends on the propensity of a particular individual to emotions of a certain kind, which is inherent in his experience and mood swings [10]. All of the above factors make it very difficult to determine the depth of influence of the emotional component on the effectiveness of the creative process in the specific characteristics of an activity and suggests opportunities for creative expression. Moreover, the ability to be creative in solving problems is not present in everyone.

At the same time, a creative approach to problemsolving requires a certain emotional state, facilitating both the successful resolution of the situation and the qualitative search for answers to all the questions posed. The history of world culture is replete with cases in which outstanding works in various genres and types of art have been created directly in periods of unprecedented emotional highs or lows for the author, manifesting the need to find an expression of his feelings in creative activity [11]. Examples of such works are the picture of I.K. Aivazovsky's "The Ninth Wave", a poem by M.Yu. Lermontov's "Death of a Poet", Mozart's famous "Requiem" and many other works of world culture. In this case, it is very difficult to determine exactly what kind and quality of emotion motivated a particular author to create a particular work - it all depends directly on his tendency to experience different kinds of emotions and psychological state directly at the time of the creation of the artistic work [12].

Emotions in art accompany the process of evaluating and understanding aesthetic values, both in specific works of world art and in the events of everyday life. This is very important from the point of view of forming values and reference points in art for future generations of artists who are able to perceive the emotions of everyday reality and display them qualitatively in their works [13]. At the same time, the ability of research and teaching staff of educational institutions where future representatives of creative professions are trained to develop their students' ability to properly perceive everyday emotions and channel them in a constructive way. This promotes the development of creative abilities of students and the education of their qualities necessary for effective creative activity in the future.

At the same time, great attention should be paid to enhancing the emotional expression of members of the creative professions while they are still in training at educational institutions. Unfortunately, at this stage in the modern education system, little attention has been paid to this really important aspect of the current education system. The development of creative skills in the learning phase should include the development of the ability to display emotions qualitatively in creative work, then creating an artwork, or conducting an art school class [14]. The ability to convey emotion in creativity is shaped in the individual through practical exercises and is already polished during the stage of his or her independent professional activity [15]. Such tasks can be successfully solved by involving students of creative specialties of educational institutions in creative 
activities that involve creating their works of art in painting, sculpture, music, decorative and applied arts.

The emotional component imposes a significant imprint on, and is in no way independent of, the various areas of activity associated with the creative processes. The influence of emotions of different kind can be manifested both in the creative rise, at which the activity and desire to "move mountains" increase, and in the emotional decline that leads to apathy and unwillingness to do anything at all. Various emotional manifestations at different stages of human activity have a significant impact on the effectiveness of the creative process, either pushing the individual to new achievements, or completely "draining" the individual. Consequently, it is not possible to unambiguously identify all the parameters and values of the influence of emotions on the effectiveness of the creative process, as this relationship is complex and ambiguous [16].

Self-fulfilment in the creative process is one of the most important aspects of personal development, with the emotional sphere playing a crucial role in this aspect. Achieving great results in various fields of creativity is impossible without living with different emotions. The individual's ability to manage his or her emotions and to channel them appropriately when the need arises is of great importance. This means that issues related to the realisation of the individual in creativity are interdisciplinary in nature and complex enough to analyse and make specific definitions [17]. Obviously, analysing the level of influence of emotional displays on the effectiveness of various creative endeavours requires knowledge of both the psychological and emotional characteristics of the individual as well as their aspirations within a particular creative activity.

Emotions in creativity can be expressed in a variety of ways, from a particular combination of colours in the palette of an artwork in the field of painting, to the emotional bursts, reflected in the musical states. In any case, the quality and completeness of the emotional impact is determined both by the artistic, aesthetic endowment of the author of a work of art and by his capacity for emotional experience and its reflection in the work of art. An important aspect is also the ability of the individual to transform a certain emotional background into images of a work of art, manifested in the formation of a certain mood, which is subsequently transmitted to the reader, viewer or listener of a work of art. The so-called emotional palette of a work of art is the main dominant feature that determines its artistic orientation and influence on connoisseurs of true art.

Emotions in creativity affect both the effectiveness of the creative process and the level of comprehension of works [18]. The author does not always manage to achieve harmony in the transfer of the emotional aspect of their work, which is expressed in a lack of understanding of some of its aspects and artistic techniques that have been used. In such cases, it must be stated that it was not possible to achieve harmony in artistic imagery, especially with regard to the transfer of the emotional component of the work of art.
Poetry, for example, offers great opportunities for personal fulfilment. Poetry, according to Brodsky, “... Poetry is the highest form of literature", and the opportunities for emotional expression in it are extremely broad. Every language of the world has great capacities to convey the emotional state of the author at the time of the creation of a poetic work, and allows the reader to fully appreciate the emotional experience of the characters, their inner world and the development of their characters. It is important to note, however, that poetry has great capacities for the emotional development of the individual, since the study of poetry contributes to the development of sensuality, which is directly linked to the emotional sphere as one of its reflections. So, poetic creativity is a wide field of activity in terms of the possibilities of emotional expression, which contributes to the development of the emotional component of an individual's life and his or her ability to perceive the environment emotionally.

Music has the same capacities for emotional expression. Musical works of different genres carry a powerful emotional charge which, depending on the vector of its application, is capable both to increase the tone, to induce active actions and achievements, and to calm, relax, inspire peace and modesty [19]. Classical musical works have different emotional connotations, providing a vivid way of conveying the emotional experiences of both the author of a piece of music and the specific characters in the case of operatic works. Classical opera music can, within the context of a single work, enable the listener to experience a wide range of emotional experiences, from the vivid to the tragic. Without a qualitative portrayal of the emotional component, no musical work can be created that can leave its mark on the treasury of world culture.

Painting is also a great way to convey the most emotional experiences. Virtually all painting styles known today contain enormous possibilities for conveying emotions of various kinds, generally determining the general thrust of this kind of art and its expressive possibilities [20]. The tones the artist chooses for his work, the combination of colours, the colour palette of the painting create a certain mood in the viewer, which is superimposed on his features of perception. It is clear that the viewer's perception of a painting is determined by his personal characteristics and aesthetic training, but the artist's ability to convey specific moods and emotional feelings through the colour scheme of the painting and a particular combination of colours is crucial in this context. The influence of the artist's emotions and his skill in conveying them in painting on visual perception is enormous and impossible to quantify and qualify [21].

The influence of emotion on the effectiveness of the creative process cannot be accurately measured, nor can it be measured by any currently available method. At the same time, the role of the emotional component in all types of artistic creativity is enormous, since without a quality display of emotion any work of art will be sluggish and will not "present" anything to an art connoisseur for his own development. Therefore, the study of the influence of emotions 
in creativity on the quality and effectiveness of the creative process will greatly enrich the existing understanding of the expressive possibilities of art, as well as any form of creative activity in general, which is important in terms of the prospects of further research on this topic.

\section{CONCLUSIONS}

A study of a wide range of issues affecting emotions on the effectiveness of the creative process has led to the following conclusions. The influence of emotion on the effectiveness of the creative process depends on a variety of factors, both those that are interrelated and those that are not. Among the main factors that matter in terms of the influence of emotions on the effectiveness of the creative process are the quality of the emotional experience of the author of the work at the time of its creation, the genre of the work, and the artistic techniques used by a particular author to convey different emotional moods in order to create the overall background of the artwork. However, the quality of the author's emotional experience does not always determine the level of the artistic work and constitutes a measure of its artistic value, since in this context the particular psychological organisation of the artist and his ability to exteriorise his emotional experience are important.

Different emotions can both motivate a creative person to produce high quality work and deprive him or her of creative expression, depending on his or her personality, self-organisation and a number of other parameters. The gradation of the influence of emotions of a certain quality on the overall effectiveness of the creative process cannot be clearly outlined, since in different situations emotions of different colours can both act as a catalyst for the creative energy process and offset creative efforts. In any case, the issue of assessing the influence of emotions of a certain quality on the effectiveness of the flow of creative processes in various fields of activity is largely debatable and requires additional research and the formation of more in-depth assessments taking into account modern concepts of assessing the quality of creative activity under the influence of emotions of various kinds.

\section{REFERENCES}

[1] Karwowski, M., \& Kaufman, J.C. (Eds.). (2017). The creative self: Effect of beliefs, self-efficacy, mindset, and identity. London: Academic Press.

[2] Jeon, M. (2017). Emotions and affect in human factors and human-computer interaction (1st ed.). London: Academic Press.

[3] Luria, S., Baer, J., \& Kaufman, J. (2018). Creativity and humor (1st ed). London: Academic Press.

[4] Preiss, D., Cosmelli, D., \& Kaufman, J. (Eds.). (2020). Creativity and the wandering mind (1st ed.). London: Academic Press.

[5] Thomson, P., \& Jaque, S. (2016). Creativity and the performing artist (1st ed.). London: Academic Press.

[6] Holikova, T.A. (1999). Dynamics of emotions of happiness and unhappiness in the work of Nabokov V.V. Culture and Text, 5, 308-312.

[7] Safin, O.D., \& Maliy, N.Yu. (2009). Psychosemantic analysis of the phenomenon of creativity in the context of creativity in professional activity. Khmelnytskyi: NADPSU.

[8] Chesnokova, N.V. (2012). The figurative characteristic of emotions of the person in S.N. Sergeyev-Tsensky's creativity. Social-Economic Phenomena and Processes, 12(046), 423-430.

[9] Runko, M., \& Pritzker, S. (2020). Encyclopedia of creativity (3rd ed.). London: Academic Press.

[10] Christensen, J., \& Gomila, A. (Eds.). (2018). The arts and the brain (1st ed.). London: Academic Press.

[11] Gupta, N., Simms, E.-M., \& Dougherty, A. (2019). Eyes on the street: Photovoice, liberation psychotherapy, and the emotional landscapes of urban children. Emotion, Space and Society, 33, article number 100627.

[12] Caballe, S., \& Clariso, R. (2016). Formative assessment, learning data analytics and gamification (1st ed.). London: Academic Press.

[13] Sydykova, R., Kakimova, L., Ospanov, B., Tobogabylova, A., \& Kuletova, U. (2018). A conceptual approach to developing the creativity of a music teacher in modern educational conditions. Thinking Skills and Creativity, 27(3), 160-166.

[14] Khessina, O.M., Gonsalo, J.A., \& Krause, V. (2018). It's time to sober up: The direct costs, side effects and long-term consequences of creativity and innovation. Research in Organizational Behavior, 38, 107-135.

[15] Pagel, J., \& Kirshtein, P. (2017). Machine dreaming and consciousness (1st ed.). London: Academic Press.

[16] Thompson, K.C., Oberle, E., Gaderman, A.M., Guhn, M., Rowdiffe, P., \& Schonert-Reichl, K.A. (2018). Measuring social-emotional development in middle childhood: The middle years development instrument. Journal of Applied Developmental Psychology, 55(3-4), 107-118.

[17] Quaglia, R., Longobardi, C., Lotti, N.O., \& Prino, L.E. (2016). A new theory on children's drawings: Analyzing the role of emotion and movement in graphical development. Infant Behavior and Development, 39(5), 81-91.

[18] Tyler, C.P., Olsen, S.G., Geldhof, G.J., \& Bowers, E.P. (2020). Critical consciousness in late adolescence: Understanding if, how, and why youth act. Journal of Applied Developmental Psychology, 70, article number 101165. 
[19] Vasquez, G.W., Ocampo, M.T.P., Brown, M.D., \& Tucker, K. (2020). Non-verbal communication, emotions, and tensions in co-production of memory: New perspectives from Peru and Colombia. Emotion, Space and Society, 37, article number 100717.

[20] Brinks, V. (2020). Fun or frustration? How emotions shape user innovation processes. Emotion, Space and Society, 34, article number 100651.

[21] Gilhooly, K., \& Gilhooly, M.M. (2021). Aging and creativity (1st ed.). London: Academic Press.

\section{Людмила Іванівна Мороз, Олександр Джамільович Сафін, Олена Олександрівна Андрусик}

Уманський державний педагогічний університет імені Павла Тичини 20300, вул. Садова, 2, м. Умань, Україна

\section{Вплив емоцій на ефективність творчого процесу}

Анотація. Актуальність заявленої тематики наукового дослідження визначається важливістю питань взаємозв’язку емоційної складової творчої діяльності з кінцевими результатами, отриманими в ході творчих пошуків різного спрямування, а також практичною значущістю дослідження проблем впливу широкого спектра емоційних переживань на загальну ефективність творчого процесу. Метою даної науково-дослідної роботи є визначення ступеня впливу емоційної складової творчої активності на ефективність творчого процесу, незалежно від сфери діяльності. Провідним підходом у даній науково-дослідній роботі було обрано поєднання теоретичного дослідження різних аспектів творчої діяльності в цілому, зі структурним аналізом особливостей впливу емоційної складової на загальну ефективність творчого процесу стосовно різних сфер діяльності. Результати, отримані у процесі даного наукового дослідження, свідчать про широкі можливості раціонального використання емоційних проявів особистості стосовно певних питань застосування творчої активності в цілому і з точки зору оцінки ефективності здійснення творчого процесу, зокрема. Результати та висновки даного наукового дослідження мають істотне практичне значення для представників творчих професій, дослідників психоемоційних проявів особистості при веденні творчої діяльності, а також будуть корисні наступним поколінням дослідників різних аспектів впливу емоційних переживань на ефективність ведення творчого процесу. Результати будуть корисні як наукова база для проведення автором подальших повноцінних досліджень широкого спектру питань, винесених на розгляд в межах даної наукової роботи, що сприятиме подальшому об'єктивному і якісному висвітленню тематики наукового дослідження

Ключові слова: творчий процес, емоційна сфера, творчі здібності, ефективність творчої діяльності, емоції у творчості 